Selçuk Esenbel (ed.),

\title{
Japan on the Silk Road: Encounters and Perspectives of Politics and Culture in Eurasia,
}

Leiden: Brill, 2018, 373 s., 23 illüstrasyon, ISBN 978-900-4274-30-3

İpekyolu ticaret, göç, inanç sistemleri ve teknolojinin yayılması konuları çerçevesinde olduğu gibi medeniyetler arası savaş veya barış köprüsü görevi görmesi ve bunun tariflerini kolaylaştırıcı bir unsur olması açısından tarih çalışmalarında karşımıza çıkmaktadır. Sıkılıkla vurgu bu yolun iki yönünde bulunan Çin ve Hindistan'ın etkisi üzerinedir. Fakat yeni çalışmalar İpekyolu'nu tek bir tanım üzerinden anlamanın mümkün olmadığını ortaya çıkarır. Yeni yaklaşımlarda eski anlatılardaki gibi yolun Çin'den batıya doğru Akdeniz'e giden bir anayol olmadı$\breve{g}$, güney ve kuzeye uzanan yan yollarla örülmüş bir ağ olduğu vurgulamaktadırlar. Ayrıca de İpekyolu ekseriyetle de kozmopolit barışın ve refahın sembolü olur. Ancak bu coğrafyaya baktığımızda yine tersi bir durum karşımıza çıkar. Özellikle de modern devlete geçiş süreçleriyle bağlantılı olarak burası bir çekişmeler coğrafyası olur. Rusya, Çin, Japonya ve diğer kolonyal Avrupa ülkeleri arasındaki yayılmaclık ve sömürgecilik savaşları, 19. yüzyıldan itibaren milli mücadele ve kimlik mücadeleleri bu çekişmeler arasında sadece birkaçı. Bu kitap 19. yüzyıl sonundan II. Dünya Savaşının sonuna kadar yükselen Meiji Japonya’sının büyük güçlere eş olma siyaseti içerisinde Osmanlı İmparatorluğu'ndan Çin'e dek uzanan İpekyolu bölgesindeki çeşitli faaliyetlerine bakmaktadır. Bu çalışma bir taraftan Japonya’nın İpekyolu ilgisini 19. yüzyıl sonu ve 20. yüzyılın ilk yarısındaki küresel siyasi ve ekonomik gelişmelerin ışığında değerlendirirken, diğer taraftan da kaynaklar aracılığıyla yerele inerek bunları Japon görüş ve algıları üzerinden sunmaktadır.

Japan on the Silk Road (İpekyolu Üstünde Japonya) bu iletişim ağlarının ortaya çıkarmaya çalışan ilginç bir denemedir. Makaleler Haziran 2012 yılında İstanbul'da gerçekleşen uluslararası bir toplantıdan sonra derlenmiştir. Japon Tarihi Emeritus Profesörü ve Boğaziçi Üniversite'nin Asya Çalışmaları'nın onursal başkanı Selçuk Esenbel'in ${ }^{1}$ editörlüğünü yaptığı kitap farklı bölgelerden gelen disiplinler arası 16 araştırmacının makalelerinden oluşmaktadır. Çalışma, 18681945 yılları arası Japonya’nın İpekyolu ile bağlarını; siyaset, dil bilimi, edebiyat,

I Aynı zamanda İstanbul 29 Mayıs Üniversitesi Tarih Bölümündedir. 
Türkiyat, mimari üzerinden örmektedir. Kitabın girişinde Esenbel'in de vurguladığı gibi 19. ve 20. yüzyıl başı Japonya’sında tarih yazımı açısından İpekyolu bir ilgi odağı iken II. Dünya Savaşı sonrasında eski devletin yayılmacılık siyasetinin bir parçası olarak görülmesinden dolayı tarihçilerin araştırma konusu olmaktan çıkmıştır (s.3). Ancak Sovyetler Birliği sonrası dönem ve Çin ile yeni politik/ ekonomik ilişkiler bu araştırmalar için yeni bir sayfa açmıştır.

Esenbel global tarih perspektifi üzerinden şekillendirilen bu kitabın İpekyolu coğrafyasına bakışta araştırmacılara düşünebilecekleri farklı örüntüler ortaya çıkardığını belirtir. Global ve Dünya tarihinin eski pratikleri, özellikle de yereli görmezden gelen ve Avrupa-merkeziyetçiliğini devam ettiren örnekleri, haklı olarak uzunca zamandır eleştiri malzemesi olmuştur. Ancak hem teorik altyapısı hem de yeni örnek çalışmaları ile son dönemde - en azından kapitalizmin küreselleşmesi, dünya sistemleri veya dünya medeniyetleri örneklemeleri olmaktan sıyrılmaya çalışan global tarih - daha fazla kabul gören transnasyonel bir bakış açısıyla yapılmaya başlandığına da dikkat çekmek gerekir. Global tarih yaklaşımında başlıca eleştiri unsuru büyük tarih yazma peşinde referans alınan kategorilerdir. Bu "global" kategoriler aslen doğu-batı gibi ikili ayrımlar ve medeniyet gibi tarihsel olmayan total genellemelerden yola çıkarak oldukça özcü, teleolojik ve sonuç olarak tek bir tarih algısı üretir. Oysa yeni tartışmalar olgu ve kavramları globelleştirmek yerine kavramlar topografyası oluşturma ve hatta global olarak çok önemsiz gibi görünen, ama bağlamları itibariyle kendi bölgelerinde çokça etki bırakan fenomenlere bakmaya önem vermektedir. ${ }^{2}$ Bu kitaptaki makaleler incelendiğinde bu tarzda bir global yaklaşımdan izler taşıdığı görülmektedir. Farklı şekilde ifade edecek olursak bu kitap İpekyolu coğrafyasını Japonya yerel tarihi ve algısı üzerinden global haritaya yerleştirme amacı güder.

Kitaptaki makaleler İpekyolu kategorisini yeni tanımlamalar ve yeni haritalandırmalar ışığında Japonya bağlantısı üzerinden bize sunmaktadır. Araştırmalar siyaset, ekonomi, askeri istihbaratın önemi 19. yüzyıl sonu ve 20. yüzyıl başı itibariyle yadsınmazken bunlara edebi hayal gücü ve kültürel kampanya (Oğuz Baykara, Satō Masako) ile teknoloji ve iletişim katmanları da eklenmektedir (Erdal Kücükyalçın, Banu Kaygusuz). Makalelerin ana temalarını şöyle sıralamak mümkündür: Emperyalist arzular peşinde koşan Japon "istihbarat süvarilerinin"

2 Samuel Moyn ve Andrew Sartori'nin ödül almış Global Entelektüel Tarih (Global Intellectual History) çalışması bir örnek olabilir. (Samuel Moyn ve Andrew (ed.), Global Intellectual History (New York: Columbia University Press, 2013).) 
bölgede yaptıkları incelemeler; bu çerçevede Asyacılık, Büyük Asya gibi fikir yapılarına etki ve tepkiler; kimlik ve reformlar şekillenirken Batılı olmayan bir modernite arayışı; bu çerçevede Doğulu, Asyalı ve Japon kimliklerini tanımlama çabaları; İslam, Budist, Altay ve Moğol unsurların bu süreçte keşfi ve kullanımı ve son olarak da Japonya'nın bu dönemdeki iletişim araçları ve teknolojik gelişimlere adaptasyonunu. Coğrafik alan olarak ise bu konular Japonya’nın kuzeyde Orta Asya’ya, doğuda Çin ve batıya doğru İslam dünyasına uzanan mekânlar resmi, ticari ve kültürel yolculukları, siyasi, biyografik ve edebi analizlerle ortaya konmuştur. Kullanılan kaynaklara baktığımızda ise birçoğu Japonya tarihçileri tarafından biliniyor olsa da Japonya dışında -ya da Batı literatüründe- edisyon kritiklerinin bulunmamasından dolayı fazla kullanılmamış oldukları gözlemlenmektedir. Dolayısıyla çalışma bu kaynakları çok daha geniş bir okuyucu ve tarihçi çevresine tanıtmaktadır.

Esenbel giriş bölümünde İpekyolu çalışmaları, ipekyolunun anlamı ve kullanımı üzerine detaylı bilgi vermektedir. Yazarların "İpekyolu” kavramını nasıl şekillendirdiklerine baktığımızda onların bu kavrama yüklenen klasik öğeleri kıran, genişleten hatta bu kavramı salt bir coğrafi bir öğe olmaktan çıkaran bir biçimde kullandıkları ortaya çıkmaktadır. Rusya, Çin, Britanya ve Amerikan emperyalizmleri içinde Japonyảnın konumunu politik olarak açıklamaya çalışan ve dönemin politik bir resmini çizen ilk makaleler bir anlamda diğer makalelerin tartışmalarına bir temel oluşturma rolündedirler. Büyük Oyun (İan Nish), Orta Asya'ya ilginin oluşması (Christopher Szilman) ve bunları izleyen General Fukushima Yasumasảnun Büyük Asya siyaseti içinde Asya ve Osmanlı coğrafyasında yaptığı istihbarat gezileri (Selçuk Esenbel) Orta Asya ve Doğu Akdeniz’in Japonya gözünden önemi ve algısına dair önemli bilgiler vermektedir.

Makalelerin başarılı bir şekilde örneklendirdikleri bir diğer mesele de kültürel yakınlık ile siyasi emeller arasındaki daimî ilişkidir. Sonuç olarak 19. yüzyılda gelişen ve 20. yüzyıla da sirayet eden emperyal yaklaşımlar siyasi iktidarı ve ekonomik çıkarları amaçlıyorsa da Japonya’nın Orta Asya araştırmalarında önemli başka yan ürünlerin de çıkmış olduğunu görüyoruz. Bu bilgiler çerçevesinde bölgenin tarihi, dilleri ve kimlikleri ile detaylı bir harita ortaya çıkmaktadır. Gezgin ve araştırmacıların Altay, Moğol ve Türkî unsurlarla karşılaşmaları yeni Türkoloji araştırmalarına ve bölgenin halkbilimi çalışmalarına yönelmesine sebep olmuştur (Katayama Akio, Klaus Rohrborn, Mehmet Ölmez). Moğolistan ve Japonya üzerinde odaklanan Li Narangoa’nın makalesi Moğollardaki ulus kavramının ortaya 
çıkması, Japonya’nın bölgeyi bir askeri üs ve ekonomik art bölge olarak tahayyülü Zenrin Kyōkai'nin kültürel kampanyaları fikriyle başarılı bir şekilde bağlanmaktadır. Burada ortaya çıkan diğer bir konu ise Japonya’nın giderek artan İslam merakıdır. Bu hem Narangoa’nın Japonya’nın Moğolistan siyaseti içindeki yerini irdeleyen makalesinde, hem de akabinde Komatsu Hisao'nın Rus Türkistan'ı üzerine olan çalışmasında görülmektedir. 1880'lerde ortaya çıkan Cedid hareketi, Japonya’nın Rus Tatar Müslümanlarından Abdürreşid İbrahim ile temasları ve onun Japonyadaki faaliyetleri bu dönemde Orta Asya’da yükselen İslam siyasetinin önemini ve Japonya’nın buradaki gelişmelere uyum siyasetini ortaya koymaktadır (Merthan Dündar).

Ancak buradaki değerli bir nokta makalelerin sırf Japonya'dan İpekyolu coğrafyasına bakış açısını göstermesi değil aynı zamanda bu coğrafya üzerinden Japonya tarihine de yeni bir perspektif getirme uğraşıdır. Japonyảnın bu dönemde Batı'dan farklı modernleşme yolunu ve anlayışını benimsemesi sıkça tekrar edilen bir olgudur. Ancak anlatı geleneğe bağlılık, devamlılık ve teknolojinin adaptasyonu üzerinden kurulur. Burada bu "kurguları" detaylandıran ve bunun sadece eski kültürün devam ettirilmesi değil, Batılı hiyerarşik anlayışlara karşı tesadüfî olmayan entelektüel bir inşayı da açığa çıkarmaktadır. Brij Tankha, Erdal Küçükyalçın ve Miyuki Aoki Girardelli'nin mimari ve gelenek odaklı makaleleri Doğu'ya Batı'dan değil de yine doğudan bakan perspektiflerin izlerini sürmektedir. Ōtani Kōzui ve Itō Chūta’nın gezilerini ve düşüncelerini inceleyen bu mimari ve sanat tarihi bağlantılı makaleler "geleneksel" Japon mimarisi ve kültürü inşasının da taslağını vermektedir. Itō Chūta İpekyolu boyunca estetik ve yapı bilgilerinin nasıl yayıldığını izlerken aynı zamanda doğu ve batı mimarlık evrimini de araştırır ve elde ettiği bulguları Batı'nın hiyerarşik ve doğrusal kronolojisi yerine birbiriyle ilintili yatay küme çizimleriyle açılar. Bu makale Japonya’nın gelenek inşası konusunda önemli bir adıma dikkat çekmektedir. Makalenin vurguladığı üzere Itō Chūta’nın "Mimarlığın Evrimi” illüstrasyonu Batıdakinin tersine yatay bir haritalandırma yaparak Japonya’nın kendisini Batı ile karşılaştırdığında bir alt-üst hiyerarşisi içinde değil de nasıl eşit bir zeminde inşa ettiğini gözler önüne sermektedir (s. 257).

Kitapta her ne kadar ilk bakışta ortak öğe sadece Japonya görünse de daha detaylı bakıldığında öznenin İpekyolu coğrafyası olduğu görülmektedir. Çalışmalarda klasik tarih anlatılarının vazgeçilmez devamlılık anlatısını kıran bir taraf da okumak mümkün. Mesela İan Nish’in Büyük Oyun ile ilgili makalesi 
bu coğrafyadaki siyasi oluşumları, kırılmalar ve tekrar dirilmeler üzerinden anlatırken bu bölgede devamlılık gibi görünenin arkasında önemli oyuncu değişiklikleri olduğuna değinir (s. 45-46). Aslen devamlılığa işaret eden tek unsur Afganistan'dır. Britanyảnın yerini Amerika Birleşik Devletleri'nin alması, Çarlık Rusya’sının yerini mirasçısı Putin Rusyàsına bırakması ve daha önce dâhil olmayan büyük Çin ve Hindistan'ın siyasete girmesi üzerine biraz daha derinlemesine düşünmek gerekir. Global ilişkilerin büyük oyunları olarak tarif bulan bu gibi olguların yerel kronolojiler üzerinden okunmadığı sürece tam da anlamlandırılamayacağı açık bir şekilde ortaya çıkmaktadır. Yani yeni bilgi ağları, gelişen arşiv çalışmaları ve bölgeler arası iletişimin artması ile eski ulus-devlet sınırlarıyla örülmüş milli tarih anlayışlarını bırakıp daha geniş bir bakış açısına yönelen yeni tarih yazımı eski konulara farklı yaklaşımları mümkün kılmaktadır. Madalyonun öteki yüzü ise yerel kronolojileri bir kenara atmadan bu geniş perspektife katkı sağlamanın zorluğudur.

Sonuç olarak kitabın İpekyolu Üstünde Japonya başlı̆̆ı, içeriği ile ilgili kısıtlı bir izlenim verebilir. Ancak makalelerin konu edindiği ilgi alanlarına bakıldığında başlığın yanıltmaması gerektiği açıkça ortaya çıkmaktadır. Kitap Japonya’nın dışa açılmasını ve yayılmacılı̆̆ını yerel bir göz ile takip ederken modern tarih araştırmacılarına da Japonların bu dönemde İpekyolu izlenimlerini aktarması açısından ayrı bir perspektif kazandırmaktadır. Son olarak da kitabın İpekyolu teması etrafında Orta Asya tarihi ile bir tartışmaya girdiğini de belirtmek gerekmektedir. Makaleler, son dönemde akademik çalışmalarda sıklıkla eleştirilen geleneksel, yani yekpare bir bakış açısıyla, Orta Asya tarihine bir karşı duruş sergilemiştir ve buranın ancak çoklu kimlik, tarih ve siyasi yapılar çerçevesinde çalışlabileceği vurgusunu yapmıştır. Elbette alan çalışmaları yapanlar için kitabın detayında çok daha fazla ayrıntı ve inceleme yapılacak konu saklıdır.

Ancak son olarak kitabın yayıncısı ile ilgili bir yorum söylenmelidir. Brill'in Japanese Studies Library (Japonya Çalışmaları Kitaplığı) serisinin altmışıncı eseri olarak yayınlanan Japan on the Silk Road birçok yönden çok değerli bir katkı olsa da ne yazık ki fiyatından dolayı sadece kütüphanelerde göreceğimiz kitaplar arasına girecektir.

\section{Özlem Çaykent}

İstanbul 29 Mayıs Üniversitesi 